\title{
FIBER MODELING ANALYSIS FOR CYCLIC FLEXURE/SHEAR BEHAVIOR OF RC COLUMNS RETROFITTED BY PRE-TENSIONED HIGH STRENGTH STEEL BARS
}

緊張 PC 鋼棒で耐震補強した $\mathrm{RC}$ 柱の正負繰り返し曲げ・せん断挙動に関するファイバーモデル解析

\author{
Mehdi BANAZADEH* and Tetsuo YAMAKAWA** \\ メヒディバナザデ，山川哲雄
}

In this paper an analytical model for RC columns considering the nonlinear behavior in both shear and flexure at the cyclic load is proposed. The main feature of this model is that the nonlinear shear distortion is added to flexure model in a series, as an uncoupled force-deformation relation, on the basis of a flexibility formulation. The monotonic shear force-distortion relation is initially calculated by Modified Compression Field Theory (MCFT). In order to improve the shear force-distortion relation derived by MCFT, a modification procedure based on experimental data is also proposed. A hysteretic model including pinching and strength degradation is employed for shear cyclic behavior. Using this model incorporated with fiber technique, an elastoplastic analysis of RC columns retrofitted by pre-tensioned high strength steel bars for earthquake resistance is performed. In fiber modeling, a spread curvature distribution is investigated in several cross sections along the member axis. The resultant flexural force must satisfy the unique bending moment diagram given by external force. A correlation study based on the analytical simulation of experimental tests which were carried out during past few years shows an excellent agreement and a perfect validity of proposed nonlinear analytical model.

Keywords: RC column, seismic retrofit, nonlinear analysis, cyclic fiber model, shear distortion, flexure deformation, modified compression field theory $\mathrm{RC}$ 柱, 耐震補強, 非線形解析, 正負繰り返しファイバーモデル, せん断ひずみ, 曲げ変形, 修正圧縮場理論

\section{INTRODUCTION}

Recently, predicting the ultimate lateral capacity in RC structures using a reliable numerical simulation has been a big challenge in the engineering world The main goals of such nonlinear analysis have been assigned in designing procedures for new RC structures, in seismic vulnerability assessment of existing structures in zones of high seismic risk as well as in the development of appropriate retrofit strategies. In order to obtain the more ductility and a suitable flexural failure type, the protection of a RC member against shear failure is the main criteria regarding the design of a resistant system for a new structure or a retrofit plan for old buildings to strengthen those elements in which the shear failure possibly can take place. As a matter of fact, in the case of short columns, the contribution of shear effects on the maximum capacity and hysteretic behavior can be remarkable. In order to retrofit the RC structures, Yamakawa and Kurashige et al. ${ }^{1)}$ have established a new retrofit technique using the pretensioned high strength steel bars to improve ductility, to prevent shear/flexuralcompression failure and to provide active/passive confinement for a RC member. Assessment procedures for this retrofit technique require an evaluation of the cyclic behavior of the retrofitted columns thereby all $k$ ind of nonlinearities are reflected. Primarily, experimental tests can be the most reliable source to evaluate the cyclic behavior of RC columns retrofitted by external pre-tensioned hoops.
However, as an alternative, using a nonlinear analysis to obtain the failure mode and hysteretic performance, for either assessment of a retrofit technique or suggestion of a new design method seems to be essential. The validity of such numerical modeling can be validated by correlation studies on varieties of test data which cover all types of loading and retrofit arrangements in RC columns

Among various methods, the macroscopic model using the fiber technique is the best compromise between simplicity and accuracy in order to formulate a nonlinear analysis for $\mathrm{RC}$ structures ${ }^{2)}$. The fiber modeling is a powerful method to estimate the inelastic behavior of RC structures by satisfaction of material cyclic constitutive laws in each fiber of sections along the RC member. Since each fiber is under uniaxial stress, only flexural behavior and its interaction with axial force can be reflected by the fiber model analysis while considering the shear effects in fiber model is not as straightforward as flexural ones. In this study a new method to combine the flexural and shear effects is suggested. The principal feature of this method is due to different sources of nonlinearities in $\mathrm{RC}$ columns which are separated through two flexure and shear subelements. An iterative procedure, then, deals with updating the tangent flexibility matrix of these two subelements, in which the flexure one is calculated using fiber modeling and the shear one is derived from an explicit shear force-distortion relation based on Modified Compression Field Theory (MCFT) $)^{3)}$ with a
* Graduate Student, Special Graduate Program for International Students, Graduate School of Engineering and Science, Univ. of the Ryukyus, M. Sc.

** Prof., Department of Civil Eng. \& Architecture, Faculty of Eng., Univ. of the Ryukyus, Dr. Eng.
琉球大学理工学研究科外国人留学生特別コース

大学院生.工修

琉球大学工学部環境建設工学科 教授・エ博 
flexibility sources are connected as though in a series. Accordingly, the tangent flexibility matrix of column element is a summation of shear and flexural one. A computational tool for nonlinear analysis in a finite element oriented program is, then, developed considering the shear and flexural cyclic behavior based on the proposed analytical model. The results of a number of experimental tests which were carried out to investigate the utilized retrofit technique are compared to analytical simulations. Moreover, based on the experimental results, a modification procedure on MCFT is proposed.

Briefly, the main objects of the paper are: 1- Suggesting a nonlinear analysis model for $\mathrm{RC}$ members considering the flexural/shear effects by which the failure mode and hysteretic behavior of a RC member can be automatically predicted. 2 Correlation studies and comparison of the analytical and experimental results to verify the validity of suggested method. 3- Suggestion of a modification procedure to improve the resultant shear force-distortion relation of MCFT.

\section{2. $M O D E L I N G ~ F O U N D A T I O N$}

As it is shown in Fig. 1, the column element is subdivided in flexure and shear subelements each describing a single effect. The Bernoulli-Euler assumption that a plane section remains plane, is the fundamental assumption of the strain distribution in formulation of this study. The interaction of bending and shear force can be achieved by combination of subelements in a series of different flexibility sources. The flexibility of flexure subelement can be calculated using the fiber model and for that of shear one, an explicit expression of shear forcedistortion relation with a hysteretic rule can be adopted. The shear hysteretic rule which is utilized in this study is the same as Filippou ${ }^{4)}$, whereas the monotonic shear-force distortion relation initially can be obtained from MCFT. However the shear strength and corresponding shear distortion $\gamma_{c r}$ can not be adequately attained by MCFT, particularly, in shon shear critical columns ${ }^{5 !}$. Consequently, based on correlation studies, a modification procedure on MCFT is established. The validity of this modification procedure is, then, verified due to a series of nonlinear FEM analyses. Using this procedure, the monotonic curve derived by MCFT can be improved to the accurate one so that it can be applied to analysis conforming with experimental results. Since two flexibility portions are in a series (see Fig. 1-e) the member tangent flexibility matrix [F] can be obtained by simply adding the tangent flexibility matrices of the constituent subelements as follows.

$[F]=\left[F_{f}\right]+\left[F_{s}\right]$

where $\left[F_{f}\right]$ and $\left[F_{s}\right]$ reflect the flexibility matrix of flexure and shear subelement respectively. During nonlinear analysis, these coefficients are to be updated individually, meanwhile their external load are equal (two springs in series).

Shear component: The shear model implemented in this study is based on an explicit definition of shear force-distortion relation of a RC member. This model consists of a concentrated translational spring of zero dimension located at each member end. Two springs are connected by an infinitely rigid bar to form the flexibility coefficient of shear deformation ( Fig. 2). The basis for deriving the flexibility matrix of this subelement is the shear force-distortion relation. Equilibrium yields the relation between shear force and end moments. The element and subelements deformation vectors in local coordinates are shown in Fig. 1. Since formulation of current study is based on the rotation of two ends of RC element (deformation vector without rigid body motion is $\left[\mathrm{U}_{\mathrm{T}}\right]_{3 \times 1}=\left[\begin{array}{lll}\theta_{\mathrm{T}} & \theta_{\mathrm{T} 2} & \mathrm{u}_{\mathrm{T}}\end{array}\right]^{\mathrm{T}}$ ), the rigid body movement must be translated using the following matrix.

$\left[a_{k}\right]_{3 \times 6}=\left[\begin{array}{cccccc}1 & 0 & -1 / L & 1 / L & 0 & 0 \\ 0 & 1 & -1 / L & 1 / L & 0 & 0 \\ 0 & 0 & 0 & 0 & 1 & -1\end{array}\right] \Rightarrow\left[a_{k}\right]_{3 \times 6} \times[U]=\left[U_{\mathrm{T}}\right]$

The relative shear deformation can be calculated by following integration:

$v_{\mathrm{s} 2}-\mathrm{v}_{\mathrm{s} 1}=\int_{0}^{l} \gamma_{\mathrm{u}} \cdot \mathrm{dx}=\gamma_{\mathrm{u}} \times \mathrm{L}$

$\gamma_{\mathrm{v}}=\mathrm{f}_{\mathrm{s}} \times \mathrm{V}_{1}=\mathrm{f}_{\mathrm{s}} \times \mathrm{V}_{2} \quad\left(\mathrm{~V}_{1}=\mathrm{V}_{2}\right)$

where $v_{s l}$ and $v_{s 2}$ are shear deformation in each element end and $\gamma_{x y}$ is the average shear strain relative to $x, y$ axes. The $f_{s}$ is tangent flexibility of shear forcedistortion relation which is shown in Fig. 2. The $V$, and $V$, are shear force at each node which equals to $2 M L L$ (symmetric nodal force). $L$ is the element length. Replacing Eq. (3) in Eq. (4) takes following form:

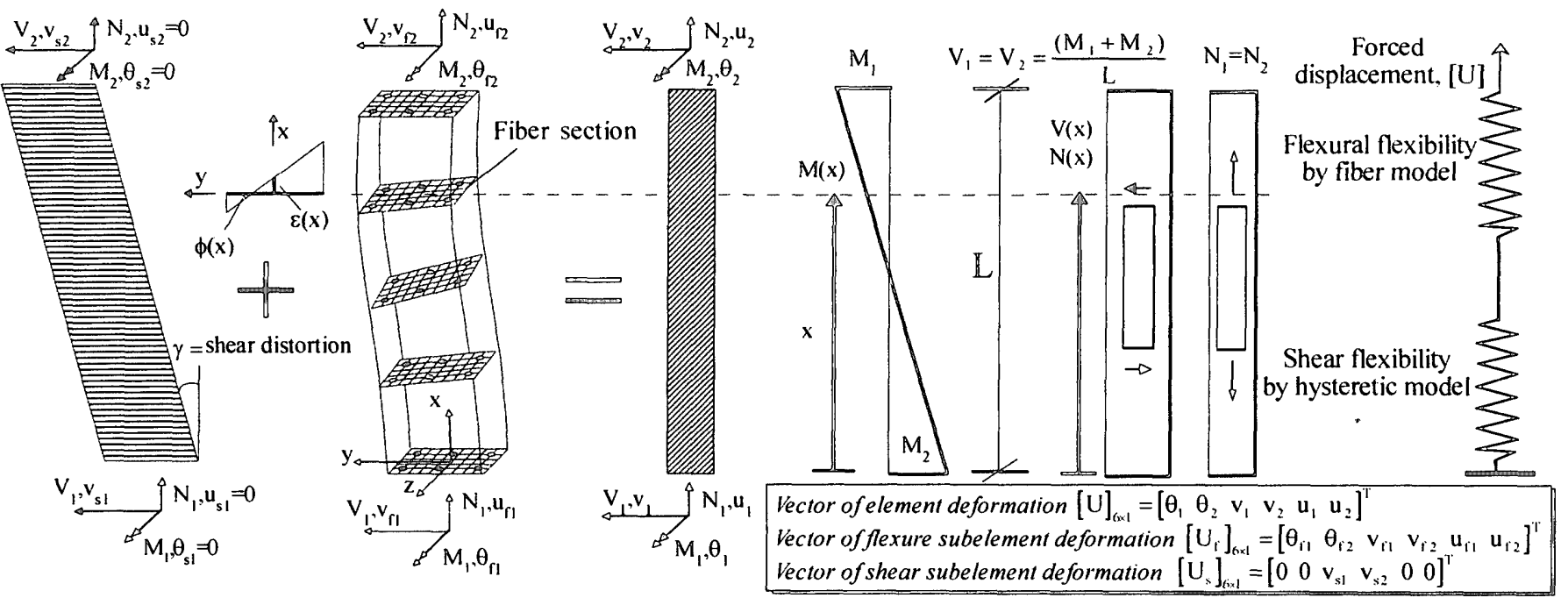

(a) Shear deformation $\begin{array}{ll}\text { (b) Flexure deformation. } & \text { (c) } \mathbb{R C} \text { element }\end{array}$ (d) Force ding rams (e) Spring model 
$v_{\mathrm{s} 2}-v_{\mathrm{s} 1}=\gamma_{\mathrm{sy}} \times \mathrm{L}=\int_{11}^{\mathrm{l}} \mathrm{f}_{\mathrm{s}} \times \mathrm{V} \times \mathrm{dx}=\int_{11}^{\mathrm{l}} \mathrm{f}_{\mathrm{s}} \times \frac{2 \times \mathrm{M}}{\mathrm{L}} \times \mathrm{dx},\left(\mathrm{V}_{1}=\mathrm{V}_{2}=\mathrm{V}\right)$

Consequently, matrix expression of Eq. (4) results in following relation for tangent flexibility matrix of shear component in element deformation.

$\left[\gamma_{N}\right]_{2,1}=\left[F_{s}\right]_{2 \times 2} \times[M]_{2 \times 1} \Rightarrow\left[F_{s}\right]=\frac{2 \times \int_{0}^{L} f_{s} \times d x}{L^{2}} \times\left[\begin{array}{ll}1 & 0 \\ 0 & 1\end{array}\right]$

Fig. 2 shows a typical nonlinear hysteretic shear force-distortion relation. This hysteretic relation has been calibrated for a shear failure type in a RC column based on test results in this study. The monotonic shear forcedistortion must be obtained using a biaxial stress-strain relation of RC members. At this time, the most applicable model for this purpose is MCFT.

Flexure fiber subelement: A displacement-based procedure is applied to formulate the distributed plasticity model in which the RC flexure subelement is represented by several cross sections located at the numerical integration points. These are known as monitoring control sections. Each section is subdivided into a number of fibers where each fiber is under uniaxial state of stress. Fig. 1-b shows the flexural deformation and a typical selection of monitoring sections along member axis of flexure subelement. For any section deformation condition (including flexural curvature and axial strain). the section flexibility and section resistant force can be calculated using fiber technique ${ }^{2)}$.

\section{SUMMARY OF NONLINEAR PROCEDURE}

The vector of element force $[P]_{(W 1}=\left[\begin{array}{llllll}M_{1} & M_{2} & V_{1} & V_{2} & N_{1} & N_{2}\end{array}\right]^{T}$, the vector of element flexural deformation $\left[U_{i}\right]_{0+1}=\left[\begin{array}{llllll}\theta_{11} & \theta_{i 2} & v_{i 1} & v_{i 2} & u_{i 1} & u_{i 2}\end{array}\right]^{T}$, the vector of element shear deformation $\left[U_{v}\right]_{G, 1}=\left[\begin{array}{lllllll}0 & 0 & v_{\mathrm{s} 1} & v_{s 2} & 0 & 0\end{array}\right]^{T}$, the vector of section flexural force $\left[S_{1:}(x)\right]_{2.1}=[M(x) N(x)]$, and the vector of section flexural deformation $\left[S_{\triangleleft}(x)\right]_{2,1}=[\phi(x) \varepsilon(x)]^{\top}$ in monitoring points are shown in Fig. 1 at local coordinates. Using the transformation matrix $\left[\mathrm{a}_{\mathrm{g}}\right]$, in order to translate the rigid body motion to ends rotation, the shear and flexural deformation vectors can be expressed as follows, respectively.

$$
\begin{aligned}
& {\left[\mathrm{U}_{\mathrm{HI}}\right]=\left[\mathrm{a}_{\mathrm{g}}\right] \times\left[\mathrm{U}_{\mathrm{i}}\right]=\left[\begin{array}{lll}
\theta_{\mathrm{TH}} & \theta_{\mathrm{TH} 2} & \mathrm{u}_{\mathrm{TH}}
\end{array}\right]^{\mathrm{T}}} \\
& {\left[\mathrm{U}_{\mathrm{Ts}}\right]=\left[\mathrm{a}_{\mathrm{g}}\right] \times\left[\mathrm{U}_{\mathrm{s}}\right]=\left[\begin{array}{lll}
\theta_{\mathrm{Ts}} & \theta_{\mathrm{Ts} 2} & 0
\end{array}\right]^{\mathrm{T}}}
\end{aligned}
$$

In addition, $\left[\mathrm{a}_{\mathrm{g}}\right]$ can express the transformation of vector $\left[\mathrm{P}_{\mathrm{r}}\right]_{3.1}=\left[\begin{array}{lll}\mathrm{M}_{1} & \mathrm{M}_{2} & \mathrm{~N}\end{array}\right]^{\mathrm{r}}$ to the vector of element force in local coordinates, $[\mathrm{P}]_{i=1}=\left[\mathrm{a}_{\mathrm{k}}\right]^{\mathrm{T}} \times\left[\mathrm{P}_{\mathrm{T}}\right]_{3,1}$ During iterative analytical procedure the corresponding force vector is $\left[P_{T}\right]$.

Section flexural deformation represented by flexure subelement can be expressed by two strain resultants: $\varepsilon(x)$ along the longitudinal axis and curvature $\phi(x)$ about reference axis of section which is assumed at center line (Fig. 1-b). The corresponding section forces are the axial force $N(x)$ and bending moment $M(x)$. Based on the well known fiber method, the section stiffiness $\left[\mathrm{k}_{\mathrm{s}}\right]$ and representing section resistant force $\left[R_{d}(x)\right]$ in flexure subelement can be derived from the section deformation. Later, using the virtual work theorem and a linear distribution for bending moment and constant for shear force (Fig. 1), the total flexural nodal residual deformation $\left[\mathrm{u}_{\mathrm{ts}}\right]^{\mathrm{m}}$ and also the new flexibility matrix for flexure subelement $\left[F_{p}\right]$ can be obtained using the following integrations.

$\left[F_{r}\right]^{m}=\int_{0}^{L}[h(x)]^{T} \times\left[f_{r}(x)\right]^{m \prime} \times[h(x)] \times d x$

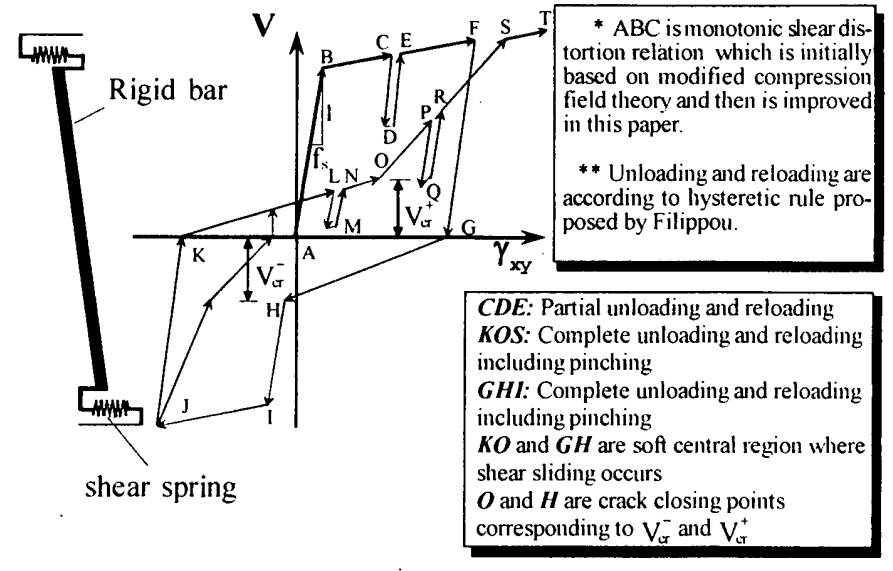

Fig. 2 Shear hysteretic model ${ }^{4)}$

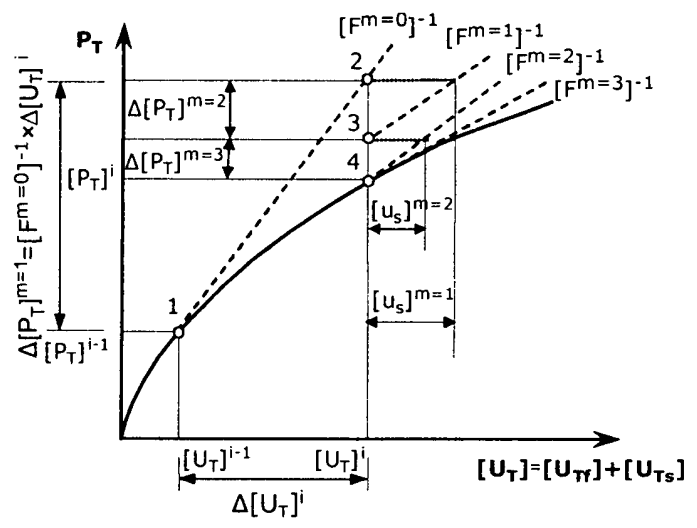

Fig. 3 Nonlinear iteration in column element

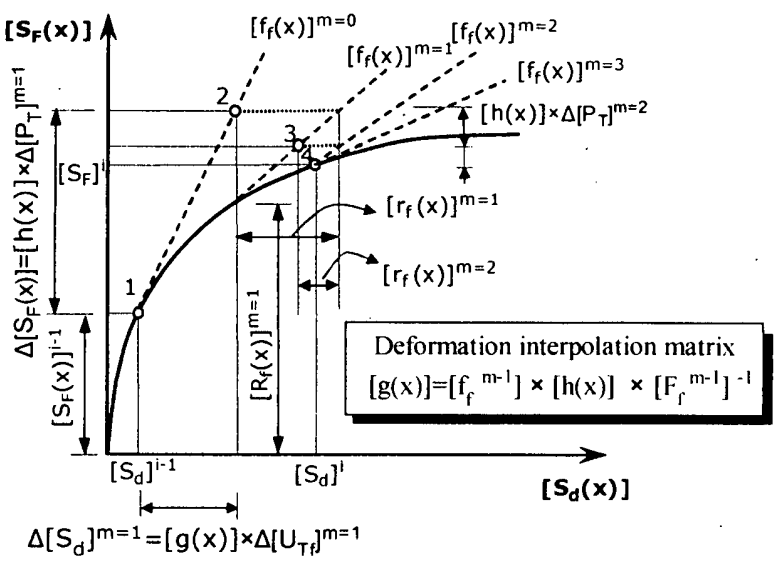

Fig. 4 Nonlinear iteration in a flexural monitoring section

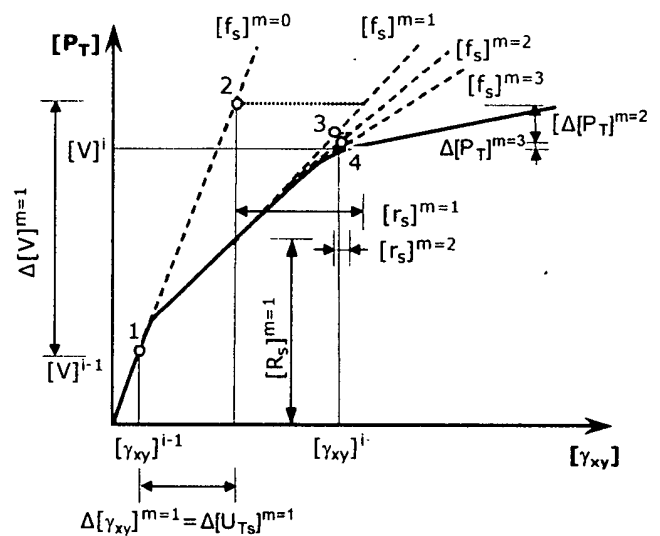

Fig. 5 Nonlinear iteration in shear subelement 


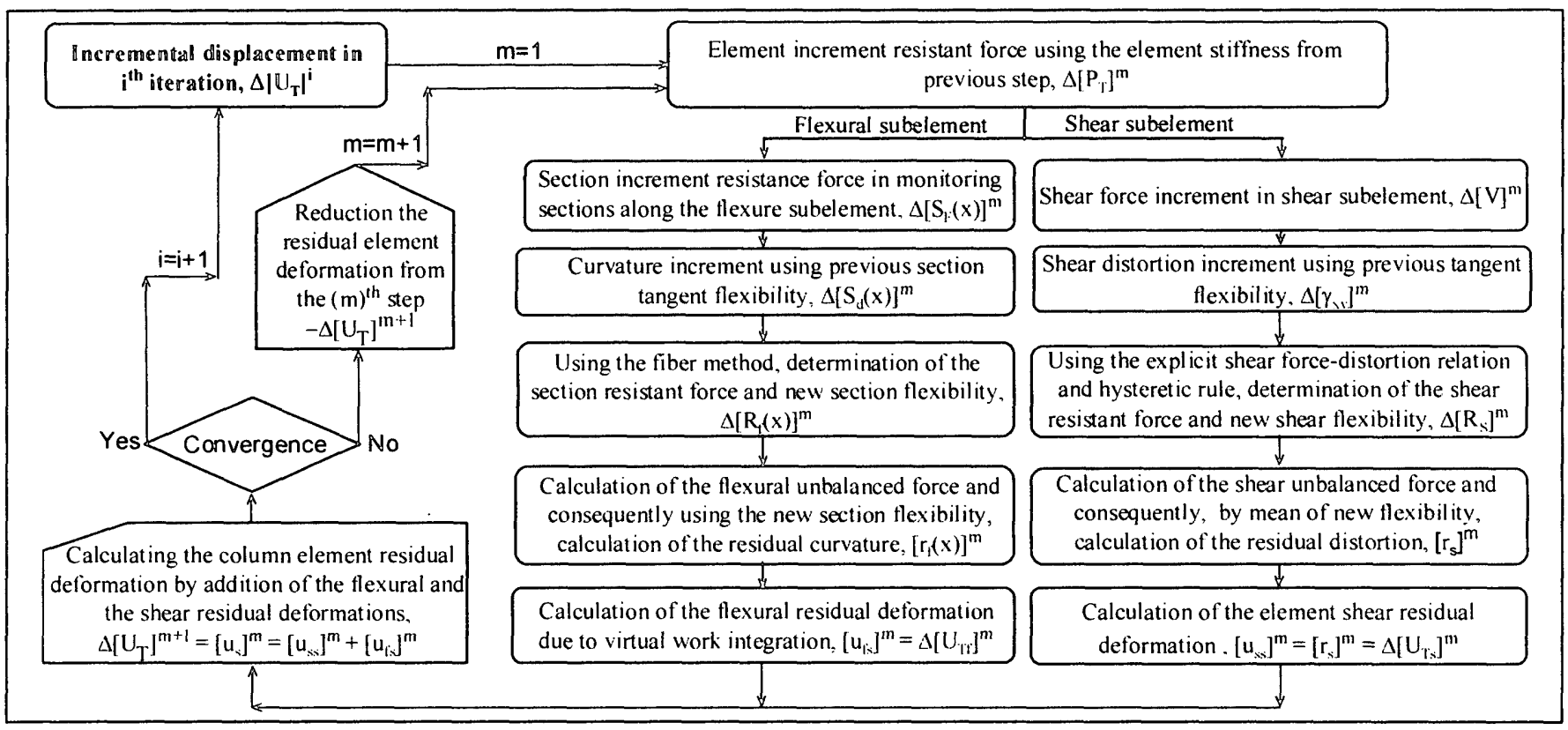

Fig. 6 Flowchart of suggested monlinear amalysis

$$
\Delta\left[U_{I I}\right]^{\prime \prime \prime}=\Delta\left[u_{i k}\right]^{m}=\int_{11}^{1}[h(x)]^{T} \times\left[r_{i}(x)\right]^{\prime \prime \prime} \times d x
$$

where $h(x)$ is a force interpolation function which is linear for moment and constant for shear force. The $[f]$ is section flexibility matrix which is the inversion of section tangent stiffiness $\left[k_{\mathrm{f}}\right]$. The integrals involved in above expressions are evaluated numerically with the Gauss-Lobatto integration scheme ${ }^{2)}$

In shear subelement, the flexibility matrix and shear resistant force can be directly calculated using Eq. (5) and hysteretic shear force-distortion relation.

During analysis, the force-displacement relation at the element level is commonly expressed in an incremental linear form such as $\Delta\left[P_{1}\right]^{m}=\left[F^{m-1}\right]^{-1} \times \Delta\left[U_{1}\right]^{m}$. where $\left[F^{m-1}\right]^{-1}$ is element tangent stiftness matrix updated at the $(m-l)^{\text {uh }}$ iteration, (for $\mathrm{m}=0 \Rightarrow\left[\mathrm{F}^{\mathrm{m}=0}\right]=\left[\mathrm{F}^{-1}\right]$ ). Indicator $(m)$ shows another nested iterative procedure inside the $f^{\text {th }}$ incremental displacement at each subelement state determination (Fig. 3). After initial prediction of element resistant force, the incremental loads of two subelements which are the same as column element ane determined based on the fact that flexure and shear subelements are connected in series (Fig. 1-e). Then, the residual deformations raised from linearization of force deformation relation in column element are calculated in each subelement. This state is known as section state determination which in flexure subelement deals with updating the deformation at each monitoring section and at shear subelement is involved with the explicit hysteretic relation of shear deformation. Consequently. the residual deformation of column element is achieved from the addition of both flexural and shear residual deformations. In order to satisfy displacement compatibility, this value should be small with an acceptable tolerance. Convergence within the $t^{t h}$ incremental displacement can be achieved by repeating this nested procedure. The equilibrium is strictly satisfied using the force interpolation matrix $[h(x)]$ and a gradual spreading of the nonlinear deformation. including the curvature and shear distortion, is exactly determined. Simultaneously. the displacement compatibility is being satisfied applying an appropriate tolerance to achieve convergence. For each subelement, state determination procedure is depicted in Figs. 4 and $\mathbf{5}$. The flowchar of the described nonlinear analysis is shown in Fig. 6.
The difference between the proposed nonlinear method and the classical ones is that in the classic nonlinear analysis, the element tangent stiffness is updated using a shape function directly, whereas in flexibility based analysis, tangent flexibility matrix must be updated first, then the tangent stiffness matrix is obtained by inverse of tangent flexibility matrix.

\section{MATERIAL CONSTRTUTtIVE MOdels}

The material constitutive law plays the main role to derive the fiber flexural effects or the explicit shear force-distortion relation. In the case of shear subelement the concrete constitutive law in compression and tension depends on the presence of transverse cracking due to $\mathrm{MCFT}{ }^{31}$. For that of flexure, generally,

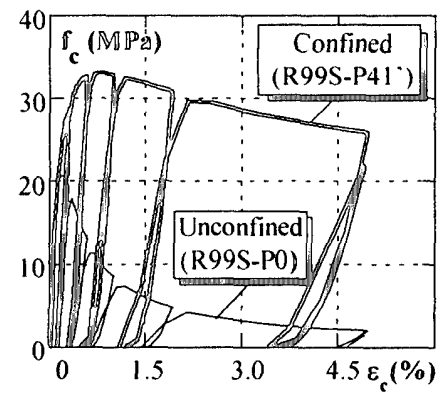

(a) Representative concrete hysteretic models, confined and unconfined (c) Steel model without buckling effect

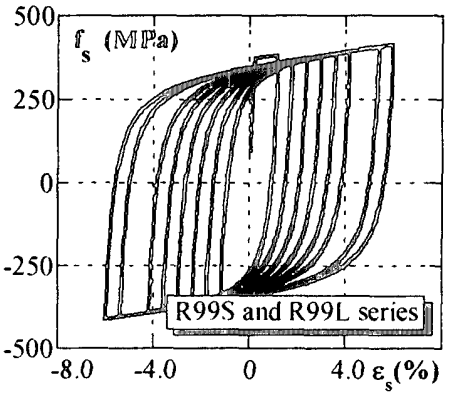

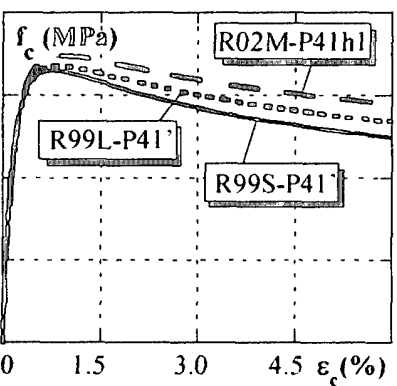

b) Monotonic concrete stress-strain

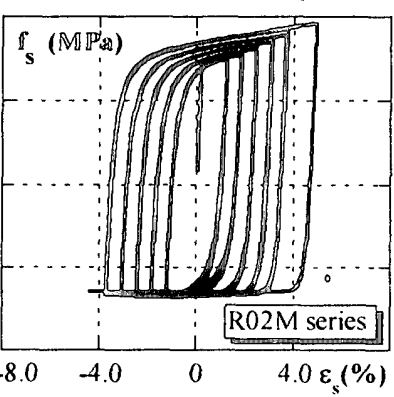

(d) Steel model with buckling effect relation for retrofitted specimens

Fig. 7 Material hysteretic constitutive laws 
three constitutive models are necessary: 1- Unconfined concrete 2- Confined concrete 3-Steel model with/without buckling. As a matter of fact, the suggested retrofit technique not only provide more transverse reinforcement but also the lateral confinement, either active or passive, which can significantly improve the concrete behavior of a $\mathrm{RC}$ member. As a result, the advantage of active and passive confinement provided by pre-tensioned external high strength steel bars must be added to passive one provided by internal hoops, using an appropriate constitutive law for concrete. In this study to consider active and passive confinement for concrete Richart ${ }^{6}$ and Mander ${ }^{7)}$ methods are adopted.

Active/passive confinement effects: Active confinement is a lateral stress due to pre-tensioned external steel bars (490 MPa for each) acting on pre-cracked and post-cracked concrete. The remained part of ultimate capacity (1202$490=712 \mathrm{MPa}$ ) can be considered as yield stress for passive confinement of external steel bars which act like transverse reinforcement, only in cracked concrete. Active confinement consideration is due to adding the $4.1 \sigma_{r} K_{e}$ to the concrete cylinder compressive strength based on Richart formula. The $\sigma_{r}$ is a uniform lateral stress due to active confinement. The $K_{e}$ is confinement effectiveness coefficient based on Mander equation. Then, the enhanced cylinder compressive strength $\left(\sigma_{B}^{\prime}\right)$ is a basic value instead of $\sigma_{B}$ which must be used in Mander equation for considering the passive confinement effect ${ }^{8)}$. Based on above explanation the concrete constitutive law is shown in Figs. 7-a and b.

For steel constitutive law, Menegotto-Pinto ${ }^{9)}$ model is employed in this study Since there is an adequate protection for cover concrete by utilized comer angles in retrofit technique, the post-elastic buckling effect under a low axial force is no remarkable. However, for more accuracy in results, except for original MenegottoPinto model, the Monti-Nutti modification ${ }^{10)}$ to include the buckling effect can be adopted in the analysis, particularly in case of a high axial load. Figs. 7-c and d show the steel model with or without buckling effects.

\section{CORRELATION STUDY \\ 5.1 EXPERIMENTAL COLUMN SPECIMENS}

The selected experimental specimens whose specification (material properties, section details and retrofit technique) are shown in Table $\mathbf{1}$ and Fig. 8, were subjected to a cyclic lateral displacement under constant axial force. Three specimens consisting of R99S-P0, R02M-P0h and R99L-P0 are shear critical ones, because of a poor arrangement of transverse reinforcement. The suggested retrofit technique was applied to the specimens R99S-P4I', R02M-P4Ihl and R99L-P41' whose shear span to depth ratios are 1, 1.5 and 2. The axial force ratios are 0.2 and 0.6 . Lateral loading cycles include three successive cycles at each drift angle range of $R=0.5,1.0,1.5,2.0,2.5,3.0 \%$ and to investigate the behavior on large forced displacement, loading test continues for $R=4 \%$ and $5 \%$ with one cycle for each. In analysis the same load pattern is used to apply forced lateral displacement on each specimen.

In order to investigate the behavior of column specimens, the shear crack strength, the ultimate shear strength, shear bond strength and flexural strength based on AIJ guidelines equations ${ }^{12)}$ as well as flexure-shear crack strength based on $\mathrm{ACl}{ }^{13)}$ are calculated. In addition, $V_{\mathrm{u}}$ based on modified Arakawa's equation is calculated in order to compare with AlJ equation. Table 2 shows the calculated results besides the experimental ones. The AIJ shear crack strength is based on the mechanical behavior of concrete which is shown by representative elements located at diagonal shear cracks with or without active confinement stress. As shown in Fig. $9 V_{c}$ is based on Mohr's circles considering the concrete tensile strength as $f_{t}=0.33 \sqrt{\sigma_{t i}}$. According to AlJ, $V_{c}$ is based on forming diagonal shear cracks, on the country, the first observed cracks during experimental tests were flexural-shear ones. The $\mathrm{ACl}$ code suggests that the shear to cause flexureshear crack $V_{c i}$ can be found by adding $0.05 \sqrt{\sigma_{B}}$ to the shear that exists when first flexural crack forms.

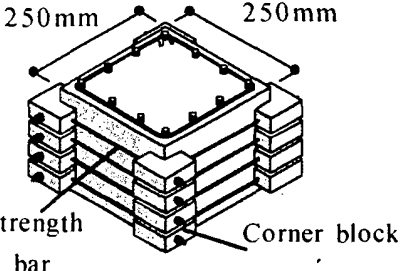

Fig. 8 Details of section and retrofit technique
Table 1 Material properties and section arrangement for test specimens

\begin{tabular}{|c|c|c|c|c|c|c|c|c|c|c|}
\hline \multicolumn{4}{|c|}{ Test specimen } & \multicolumn{2}{|l|}{ Hoop } & \multicolumn{2}{|c|}{ Reinforcement } & \multicolumn{3}{|c|}{ High strength steel bar } \\
\hline $\begin{array}{l}\text { Column } \\
\text { specimen }\end{array}$ & $\begin{array}{c}\sigma_{13} \\
(\mathrm{MPa}) \\
\end{array}$ & $\frac{M}{V D}$ & $\frac{N}{b D \sigma_{13}}$ & Arrangement & $\begin{array}{c}\sigma_{y} \\
(\mathrm{MPa})\end{array}$ & Arrangement & $\begin{array}{c}\sigma_{y} \\
(\mathrm{MPa})\end{array}$ & Arrangement & $\begin{array}{c}\sigma_{y} \\
(\mathrm{MPa})\end{array}$ & $\begin{array}{c}\text { Pre-tensioned } \\
\text { stress } \\
(\mathrm{MPa})\end{array}$ \\
\hline R99S-P0 ${ }^{11}$ & 207 & 1 & ? & \multirow{6}{*}{$\begin{array}{c}3.7 \phi-@ 105 \\
(0.08 \%)\end{array}$} & 333 & \multirow{4}{*}{$\begin{array}{l}12-\mathrm{D} 10 \\
(1.38 \%)\end{array}$} & \multirow{4}{*}{371} & - & - & - \\
\hline R99S-P41' ${ }^{11}$ & 20.1 & 1 & 0.2 & & 335 & & & $5.4 \phi-@ 41$ & 1202 & 490 \\
\hline R02M-P0h ${ }^{(1)}$ & \multirow{2}{*}{22.3} & \multirow{2}{*}{1.5} & \multirow{2}{*}{0.6} & & \multirow{2}{*}{391} & & & - & - & - \\
\hline R02M-P4lh1"11) & & & & & & & & $5.4 \phi-(a) 41$ & 1202 & 490 \\
\hline R99L-P0 ${ }^{\prime \prime}$ & \multirow{2}{*}{21.2} & \multirow{2}{*}{2} & \multirow{2}{*}{0.2} & & \multirow{2}{*}{333} & \multirow{2}{*}{$\begin{array}{l}12-\mathrm{D} 13 \\
(2.44 \%)\end{array}$} & \multirow{2}{*}{360} & - & 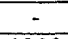 & - \\
\hline R99L-P41, 1) & & & & & & & & $5.4 \phi-@ 41$ & 1202 & 490 \\
\hline
\end{tabular}

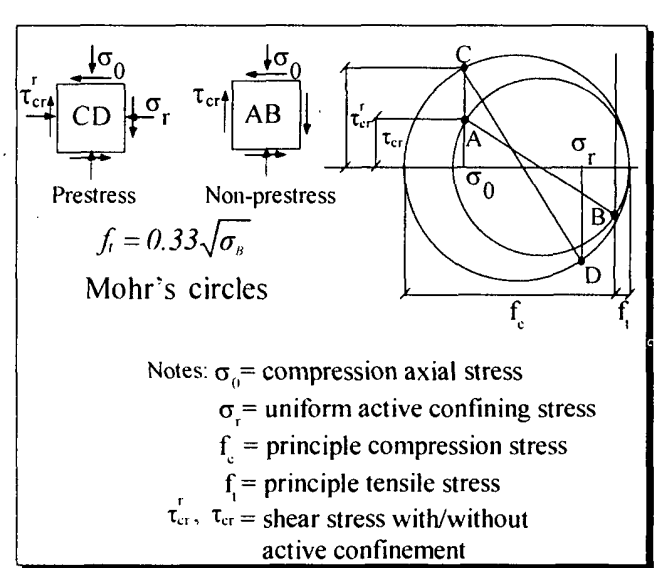

Fig. 9 Active confinement effect on shear crack strength
Table 2 Shear crack strength, flexure-shear crack strength, ultimate shear strength, bond strength and observed experimental results

\begin{tabular}{|c|c|c|c|c|c|c|c|c|c|c|c|}
\hline & \multirow{2}{*}{$\begin{array}{c}\sigma_{\mathrm{B}}^{\prime} \\
(\mathrm{MPa})\end{array}$} & \multirow{2}{*}{$\begin{array}{c}\dot{f}_{c c} \\
(\mathrm{MPa})\end{array}$} & \multirow{2}{*}{$\begin{array}{c}V_{c} \\
(k N)\end{array}$} & \multirow{2}{*}{$\begin{array}{c}\mathrm{V}_{\mathrm{ci}} \\
(\mathrm{kN})\end{array}$} & \multicolumn{2}{|c|}{$V_{u}(k N)$} & \multirow{2}{*}{$\begin{array}{c}\mathrm{V}_{\mathrm{b}} \\
(\mathrm{kN})\end{array}$} & \multirow{2}{*}{$\begin{array}{c}\mathrm{V}_{\mathrm{f}} \\
(\mathrm{kN})\end{array}$} & \multirow{2}{*}{$\begin{array}{l}V_{\text {cup }} \\
(k N)\end{array}$} & \multirow{2}{*}{$\begin{array}{l}R_{\text {cyp }} \\
(\%)\end{array}$} & \multirow{2}{*}{$\begin{array}{l}\text { Failure } \\
\text { type }\end{array}$} \\
\hline & & & & & $\mathrm{AlJ}$ & Arakawa & & & & & \\
\hline R99S-P0 & - & - & 121.2 & 79.6 & 96.2 & 121.3 & 125.6 & 204.0 & 119.2 & 0.48 & S \\
\hline R99S-P4I' & 22.9 & 33.0 & 139.1 & 80.0 & 243.8 & 185.6 & 243.8 & 212.0 & 215.8 & $>5$ & $\mathrm{~F}$ \\
\hline $\mathrm{R} 02 \mathrm{M}-\mathrm{P} 0 \mathrm{~h}$ & - & - & 201.5 & 122.2 & 90.1 & 119.7 & 136.6 & 125.0 & 116.2 & 0.35 & S \\
\hline R02M-P4Ihl & 24.5 & 34.8 & 256.2 & 123.7 & 291.5 & 236.4 & 291.5 & 213.0 & 210.7 & 0.93 & $\mathrm{~F}-\mathrm{C}$ \\
\hline R99L-P0 & - & - & 123.2 & 47.0 & 70.2 & 100.3 & 111.7 & 142.0 & 103.0 & 0.50 & $\mathrm{~S}$ \\
\hline R99L-P4I' & 23.4 & 33.5 & 142.6 & 48.3 & 236.0 & 151.2 & 236.0 & 146.0 & 139.0 & $>5$ & $\mathrm{~F}$ \\
\hline
\end{tabular}

Notes: $\sigma_{13}^{\prime}=\sigma_{13}+4.1 \sigma_{\mathrm{r}} \mathrm{K}_{v}, \sigma_{13}=$ concrete cylinder compressive strength, $\mathrm{f}^{\prime}{ }_{\mathrm{c}}=$ concrete peak confined strength, $\mathrm{V}_{v}=$ AlJ shear crack strength, $\mathrm{V}_{\mathrm{ci}}=\mathrm{ACl}$ flexure-shear crack strength, $\mathrm{V}_{\mathrm{u}}=$ ultimate shear strength based on either AlJ equation or modified Arakawa's mean equation, $\mathrm{V}_{\mathrm{b}}=\mathrm{All}$ s shear bond slip strength, $\mathrm{V}_{\mathrm{f}}=$ AI.J simplified flexural strength, $V_{\text {exp }}=$ experimental capacity, $R_{\text {exp }}=$ observed drift angle corresponding to $V_{\text {evp }}$, the $V_{c}$ is based on the Mohr's circle shown in Fig. 9 either including active confinement or not, $\mathrm{S}=$ shear failure, $\mathrm{F}=$ flexural failure, $\mathrm{F}-\mathrm{C}=$ flexural-compression failure 


$$
\mathrm{V}_{\mathrm{ci}}=0.05 \times \sqrt{\sigma_{\mathrm{B}}} \times \mathrm{b} \times \mathrm{d}+\frac{\mathrm{V}}{\mathrm{M}} \times \mathrm{M}_{\mathrm{cr}} \geq 0.14 \times \sqrt{\sigma_{\mathrm{B}}} \times \mathrm{b} \times \mathrm{d}
$$

where $V / M$ is the shear-to-moment ratio at the section under consideration and $M_{c r}$ is the moment required to cause flexural cracking at the section. Flexural cracking is assumed to occur when the normal tensile stress reaches $0.5 \sqrt{\sigma_{B}}$. The $b$ is section width and $d$ is section effective depth. When lateral confinement, $\sigma^{*}$ is substituted instead of $\sigma_{B}$ in Eq. 11. In fact, AIJ shows a remarkable improvement in $V_{c}$ due to active confinement. However for flexure-shear crack strength $V_{c i}^{\prime}$, based on Eq. (11), the improvement effect is not considerable. For R99S-P0 and R99L-P0, $V_{c}$ is resembled to $V_{\text {exp }}$. In R02M-P0h, since the principal compressive stress reached to concrete compressive strength before principal tensile stress reached to $f_{i}$, the value of $V_{c}$ which is based on tensile strength is overestimated. As shown in Table 8 after retrofitting by pre-tensioned high strength steel bars $V_{n}$ according to AIJ is largely improved and the shear failure in standard specimens changes to a flexural one. As a matter of fact, the shear strength calculated by modified Arakawa's mean equation is better estimation for assessment of specimens with poor transverse reinforcement. However in assessment of test specimens with an adequate amount of transverse reinforcement AlJ presents better estimation ". The $v^{\prime}$ "based on modified Arakawa's equation is extremely conservative after retrofit, particularly, in specimens R99S-P41' and R99L-P4I' is even less than flexural strength. Taking advantage of active/ passive confinement, a large ductility can be achieved after retrofit. This can be attributed to not only the active confinement but also the increase of transverse reinforcement. Apart from shear strength improvement, utilized retrofit technique also increases the bond strength. In order to calculate the shear bond strength based on AIJ, the transverse reinforcement provided by internal hoops and external steel bars as well as the improvement effect of lateral active confinement on concrete compressive strength $\sigma_{B}^{\prime}$ have been considered. In fact. $V_{b}$ after retrofit is equal to $V_{\|}$whereas both are significantly improved rather than before retrofit and no bond failure was observed ${ }^{1}$.

Based on experimental observations for shear failures, the range of drift angle corresponding to ultimate shear strength is between $0.35 \%$ and $0.50 \%$. After retrofit, for a flexural failure a drift angle up to $5 \%$ and for a flexural-compression failure a drift angle up to $2.5 \%$ can be achieved.

\subsection{MODIFICATION OF MODIFUED COMPRESSION FUELD THEORY}

What is Modified Compression Field Theory (MCFT) ${ }^{3)}$ ? MCFT is an analytical model in order to predict the shear force-distortion response of RC elements subjected to in-plane shear and normal stresses. In this model cracked concrete is treated as a new material with its own stress-strain characteristics. In the earlier Compression Field Theory it was assumed that cracked concrete is capable to transmit the shear stress across cracks by aggregate interlock and there is no tensile stress between cracks. Based on experimental tests, a constitutive law for cracked concrete which is weaker than non-cracked concrete was established. Then, due to considering the equilibrium for average stress and compatibility for average strain, the shear force-distortion relation was predicted by Compression Field Theory. Later during the new experimental tests significant tensile stresses were found in the concrete between cracks even at very high values of average tensile strain. Actually considering the tensile strength between cracks changed the name of earlier Compression Field Theory to Modified Compression Field
Theory. The software of Response-2000 is used to calculate the shear forcedistortion relation based on MCFT in this study.

Irasufficiencies of MCFT ${ }^{5), 1-1), 15)}$ : Although, MCFT is a powerful analytical tool, but there are some insufficiencies as follows. In case of shear span to depth ratio less than about 2 , MCFT can be expected to give a conservative result for shear strength. Also in case of shear failure type with a poor arrangement of transverse steel the predicted shear distortion corresponding to peak shear strength is extremely smaller than the experimental test results.

When poor arrangement of transverse steel, after initiating the shear cracks, MCFT yields the maximum shear strength followed by a descending line corresponding to strength deterioration. In representative experimental tests, in case of shear failures the ultimate shear strength occurred before forming the plastic hinge. Also for those of flexural failures , as a result of the applied retrofit, there was no shear strength degradation after forming the plastic hinge. When shear failure, the softening branch can be predicted by MCFT properly, however, in the cases with shear span to depth ratio less than about 2 the calculated shear strength and corresponding shear distortion seems to be inadequate ${ }^{5 \%, 14)}$. Generally, for producing a trilinear monotonic curve, the stiffness before and after shear cracks plus the point from which the intensive cracks happen must be known. For flexural failure with any shear span to depth ratio the crack point can be accurately predicted by MCFT. On the other side, when poor arrangement of transverse reinforcement, particularly in short columns, instead of MCFT shear strength can be adequately calculated due to a simplified formula based on the well known truss arch analogy such as AIJ method "I) or modified Arakawa formula "). As shown in Tabte 2, in the case of shear critical spocimens, the type of failure can be distinguished by both, however, the absolute value of shear strength by Arakawa is better estimation comparing to test results.

The suggested modification procedure: A modification procedure on MCFT which is consisting of two different viewpoints for flexural and shear failure is established as follows.

Shear failure: Based on experimental tests in current research ( Table 2) as well as the suggestion by Tomii et al. ${ }^{16)}$, it is deemed that the best choice of $\gamma_{c r}$ thereby the analysis results in rational hysteretic deformation is about $0.4 \%$. In addition, using a micro model by FEM method, due to a smeared crack model and Drucker-Prager failure criterion for concrete, a number of nonlinear analyses are carried out to investigate the shear force-distortion relation of shear critical columns (see Fig. 11). Using the value $\gamma_{c r}=0.4 \%$ in modified curve representing the engineering shear strain corresponding to shear strength, an excellent hysteretic force deformation relation of shear failure type can be obtained from analysis. Therefore, the modification procedure is as follows: 1 - Producing the original curves by MCFT 2-Calculation of shear strength $\left(V_{u}\right)$ by MCFT, AIJ or modified

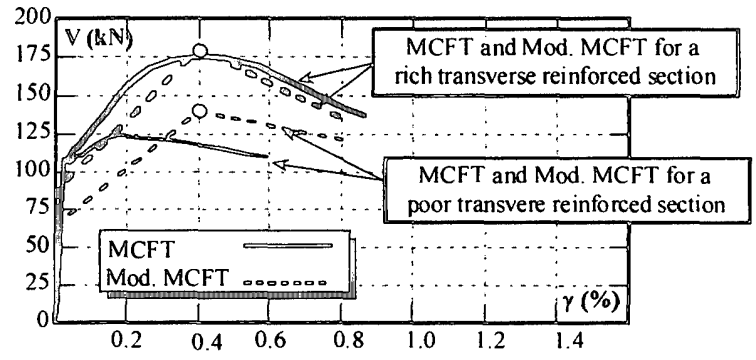

Fig. 10 Typical comparison for shear force-distortion relation between MCFT and suggested madification in this study 


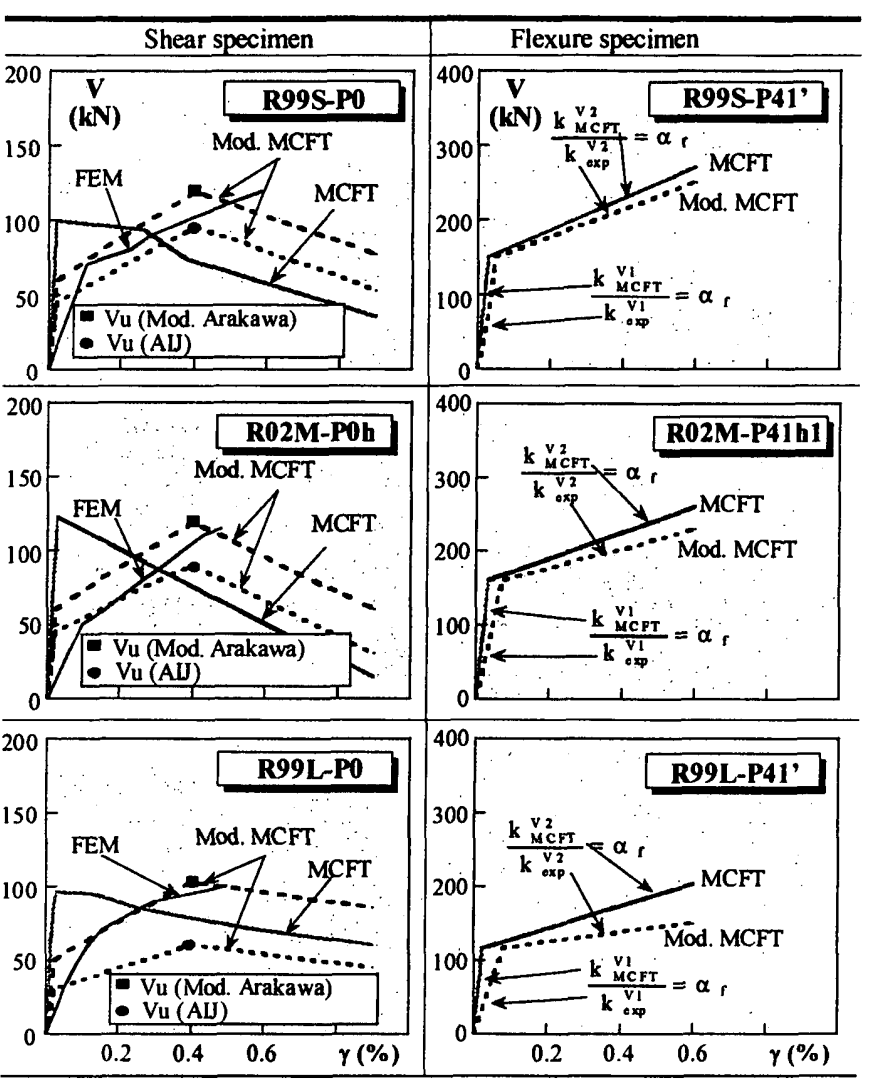

Fig. 11 Modified shear force-distortion relation

Arakawa 3- Connection the point $0.5 V^{\prime}$ from original curve to the point with shear strength of $V_{n}$ and shear distortion of $0.4 \%\left(0.5 V_{\prime \prime}^{\prime}\right.$ is a good compromise for flexure-shear crack strength based on test results and analysis) 4 - The softening branch is parallel to that of original curve. As shown in Fig. 10, the trilinear modified MCFT curve for a rich transverse reinforced section is resemble to original MCFT curve, however, for a poor one is totally different. Fig 11 shows the modified curves for representative column specimens in correlation study.

Flexural failure: The modification procedure in a flexural failure is due to reduction of stiffness of pre-crack and post-crack branch in monotonic curve ( $k_{\mathrm{MCFT}}^{\mathrm{VI}}, k_{\mathrm{MCFT}}^{\mathrm{V} 2}$ ), derived by MCFT. First, the original monotonic curve of MCFT is employed in analysis. Then, for each retrofitted specimen a reduction factor is

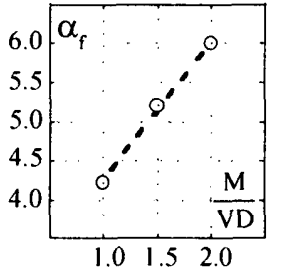

Fig. 12 Modification factor of MCFT multiplied on this curve to conform the analytical hysteretic loops to test results. The reduction factor $\alpha_{f}$ for all specimens is shown in Fig. 12. The equation which is the best fitting curve for $\alpha_{f}$ against $M^{\prime}(V D)$ can be expressed as follows:

$\alpha_{\mathrm{f}}=1.78 \times \frac{\mathrm{M}}{\mathrm{VD}}+2.47$

The modified curves are shown in Fig. 11.

\subsection{COMPARISON OF ANALYSIS AND EXPERIMENT}

The proposed analytical model is utilized to provide a computational tool in a finite element oriented environment. Then, the validity of described method is numerically verified. Comparison between experimental and analytical results

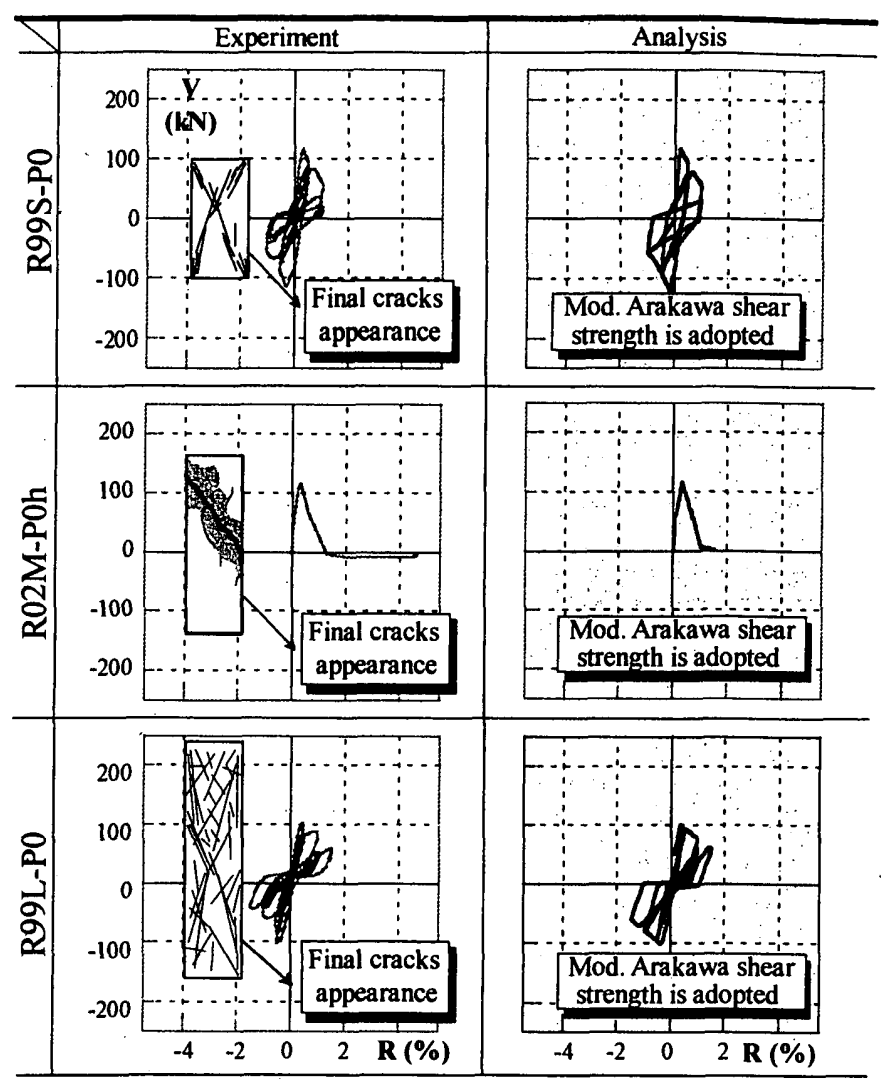

Fig. 13 Comparison of experimental and analytical V-R relations for non-retrofitted column specimens

for shear and flexural failure is depicted in Figs. 13 and 14. Generally, there is an excellent agreement between analytical and experimental results. The hysteretic shear deformation $(K-R)$ in non-retrofitted specimens is adequately predicted by analysis. Since all standard specimens are shear critical (Fig. 13), the whole deformation history is affected by shear subelement and longitudinal reinforcements are not yielded. In the retrofitted specimens with flexural failure type (Fig. 14), the effect of shear deformation before yielding the longitudinal reinforcement is remarkable. However, the behavior is governed by flexural effects after yielding the rebars. For all flexural failure cases there is an outstanding agreement between experimental results of average vertical strain $\left(\varepsilon_{1}\right)$ vs. drift angle $(R)$ and that of analytical results. The $\varepsilon_{v}$ is calculated due to dividing the relative vertical displacement between top and bottom by member height. The shear force-distortion relation for all specimens first is calculated by MCFI and later is modified using the proposed procedure.

\section{CONCLUSIONS}

The suggested nonlinear analysis in which the flexural behavior is extracted from a distributed curvature formulation among monitoring sections along the member axis using fiber modeling, and shear behavior is obtained by an explicit shear force-distortion relation, can be successfully implenented in RC members. The suggested modification procedure on shear force-distortion relation, which is based on experimental data can be applied to improve the results of MCFT. The behavior of shear critical short columns before and after retrofitting by pretensioned steel bars (shear failure before and flexural failure after) can be automatically predicted by the suggested modeling procedure. The analytical results which agree well with experimental ones show a remarkable improvement 


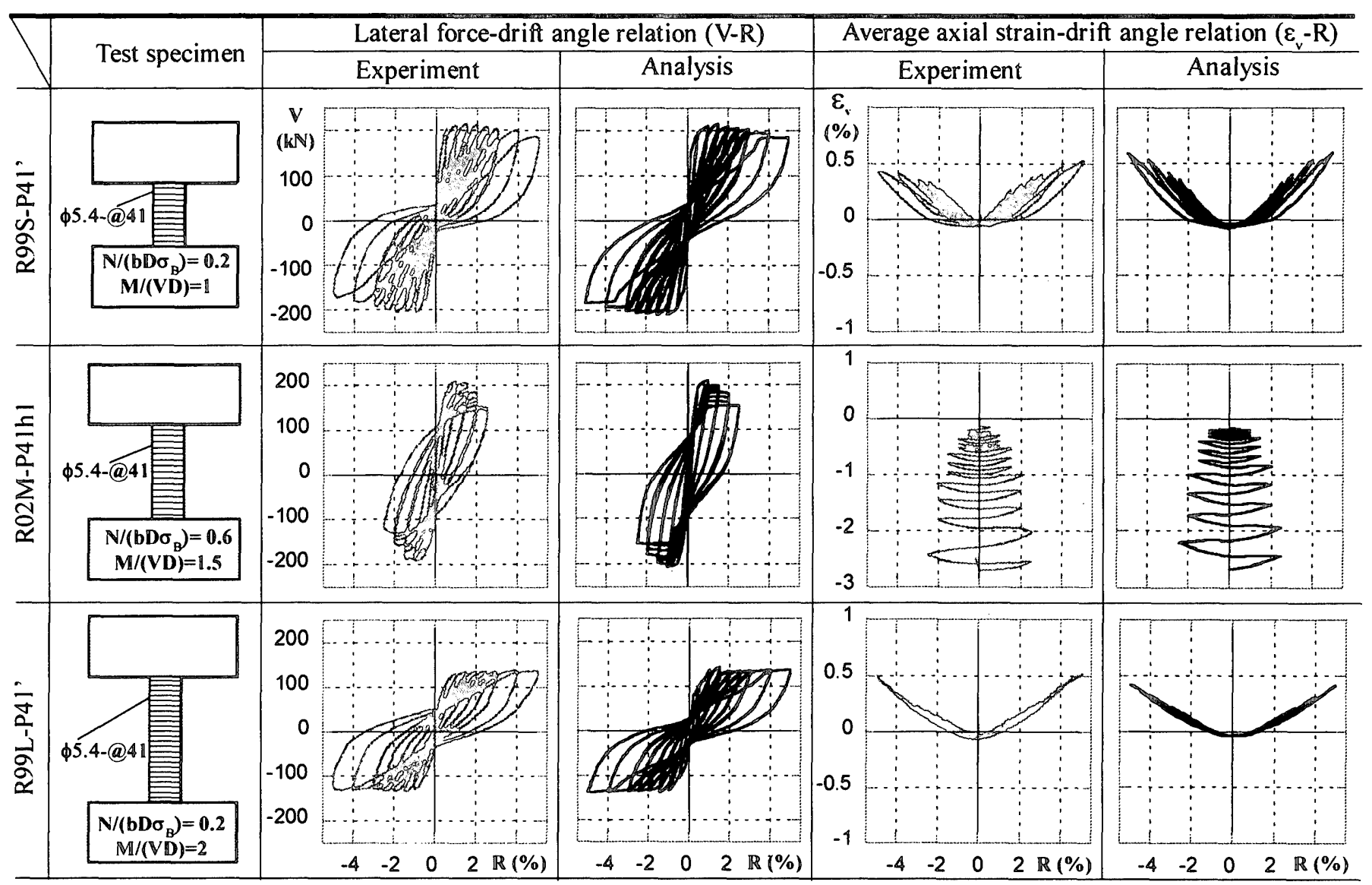

Fig. 14 Comparison of experimental and analytical results of the retrofitted column specimens

in lateral ductile behavior of shear critical columns after retrofitting by pretensioned high strength steel bars. The suggested analytical model is only appropriate in case of a perfect bond between concrete and rebars. Also it is assumed that there is no shear strength degradation in the plastic hinge zone due to a flexural failure type. MCFT is not appropriate when there is a shear strength degradation in plastic hinge zone. Numerical modeling of this phenomenon is one of the complicated research topics in engineering world, specially for such macro modeling approach used in this paper. In future, the consideration of the bond slip effects on hysteretic behavior of a RC members as well as the shear strength degradation at plastic hinge zone are two upcoming research issues for current study. A full discussion about correlation study including the more experimental data is hopefully presented in the near future.

\section{ACKNOWLEDGMENTS}

This work was supported by Grant-in-Ant for Scientific Research (B) 14350306, Japan Society for the Promotion of Science (JSPS). The multi-disciplinary numerical computation program MATLAB Ver. 6.5, a comprehensive finite element oriented program opensees 1.5 (Earthquake Engineering Research Center), Response-2000 for Modified Compression Field Theory which is available at www.ecf.toronto.edu -bentzhome.shtml and the general Finite Element Code of Ansys 5.4 are used in numerical analysis of current research.

\section{REFERENCES}

1) Yamakawa, T., Kamogawa, S. and Kurashige, M. : Seismic Performance and Design of RC Columns Retrofitted by PC Bar Prestressing as Extemal Hoops, J. Struct. Eng., AIJ, No. 537, 107-113, Nov., 2000 (In Japanese)

2) Spacone, E., Filippou, F. and Taucer., F. : Fiber Bean-Column Model for Non-linear Analysis of R/C Frames: Part 1. Formulation, J. Earthquake Engineering and Structural Dynamics, Vol. 25, 711-725, 1996
3) Vecchio, F. J. and Collins, M. P. :The Modified Compression-Field Theory for Reinforced Concrete Elements Subjected to Shear, ACl Journal,Vol. 83, No. 2, 219-231, 1986.

4) D'Ambrisi, A. and Filippou, F. : Modeling of Cyclic Shear Behavior in RC Members, J. of Structural Engineering, ASCE, Vol. 125, No. 10, 1143-1149, 1999

5) Bentz, E.C. : Sectional Analysis of Reinforced Concrete Members, PhD Thesis, Department of Civil Engineering, University of Toronto, 310-311, 2000.

6) Richart, F. E., Brandtzang, A., and Brown, R. L. : A Study of Failure of Concrete under Combined Stresses, Engineering Experimental Station, Bulletin No. 185, University of Illinois, Urbana, 1928

7) Mander, J. B., Priestley, M. J. N., and Park, R. : Theoretical Stress-Strain Model for Confined Concrete, J. Struc. Eng., ASCE, Vol. 114, No. 8, 1804-1826, 1988.

8) Yamakawa, T. and Li, W. : Seismic Retrofit Design of Columns with Spandrel Walls Utilizing Pre-tensioned High Strength Steel Bars and Steel Plates, J. Struct. Constr. Eng., AIJ, No. 577, 93-100, Mar., 2004 (In Japanese).

9) Menegotto, M, and Pinto, P. E. : Method of Analysis for Cyclically Loaded Reinforced Concrete Plane Frame Including Changes in Geometry and Nonelastic Behavior of Elements under Combined Normal Force and Bending, IABSE Symp. on Resistance and Ultimate Deformability of Structures Acted on by Well-defined Repeated Loads, Final report, Lisbon, 1973

10) Monti, G. and Nuti, C. : Nonlinear Cyclic Behavior of Reinforcing Bars Including Buckling, J. Struc. Eng., ASCE, Vol. 118, No. 12, 3268-3284, 1992.

11) IIhoshii, F., Yamakawa, T., Li, W. and Nakada, S. : Seismic Retrofit by PC Rod Prestressing for Brittle Columns under High Axial Compression, Proceeding of the Japan Concrete Institute, JCl, Vol. 25, No 2, 1531-1536, 2003 (In Japanese).

12) AlJ : Design Guidelines for Earthquake Reinforced Concrete Buildings Base on Inelastic Displacement Concept, AlJ, 1999 (In Japanese).

13) $\mathrm{ACl}, \mathrm{C} .318$, :Building Code Requirement for Reinforced Concrete ( $\mathrm{ACI}$ 318-89) and Commentary-ACI 318 R-89, American Concrete Institute, Detroit, 352-353, 1989.

14) Vecchio, F. J. : Analysis of Shear-critical Reinforced Concrete Beams, ACI Struct. J., 102. $110,2000$.

15) Priestley, M. J. N. and Seible, F. : Seismic Design and Retrofit of Bridges, A WileyInterscience Publication, 331-332, 1996.

16) Tomii, M. and Takeuchi, M. : The Relation between the Deformed Angle and the Shearing Force Ratio $(0.80 \sim 1.00)$ with regard to 200 Shear Walls, Transaction of AlJ, No $153,41-48,1968$. 


\section{和文要約}

1. 序

近年、信頼できる数值解析手法で $\mathrm{RC}$ 構造物の終局強度を精度よく 予測することが求められている。勒性に富んだ曲げの弹塑性举動を得 るために、RC 部材におけるせん断破壊防止が新築の $\mathrm{RC}$ 造建物や、 古い建物の耐震補強計画の基本になる。実際のところ、短柱では耐力 や履歷挙動にせん断強度が大きな影響を与えている。山川・倉重らは、 緊張力を導入した高強度鋼（PC 鋼棒）を利用した RC 構造物の新し い耐震補強法を提案した。この耐震補強法に対寸る評価として、補強 柱の正負繰り返し举動を解析することが求められる。もっとも、補強 $\mathrm{RC}$ 柱の正負繰り返し举動を評価するためには、加力実験が最も信頼 できる方法であることは言うまでもない。しかしながら、実験に代っ て非線形解析は、耐震補強の開発や新しい設計手法にとって重要であ る。このような数值解析の信頼性は、RC 柱に関する数多くの実験結 果との照查で検証される。

各種の解析手法のなかで、 $\mathrm{RC}$ 構造物の非線形解析における簡単さ と高精度の観点から、ファイバーモデルを利用したマクロ解析モデル が望ましい。ファイバーモデルは RC 部材の各断面で正負絽り返し構 成則を満足させることにより、 $\mathrm{RC}$ 構造物の非線形举動を予測できる 強力な解析モデルである。各ファイバーは 1 軸応力状態を取り扱うの で、曲げ举動や軸力と曲げの相互作用は反映できるが、ファイバーモ デルにせん断の影響を考虑することは困難である。本解析では曲げと せん断の影響を組み合わせた新しい方法を提案する。この方法の主な 特徵は RC 柱の非線形性を、曲げとせん断の副要素に分離して取り扱

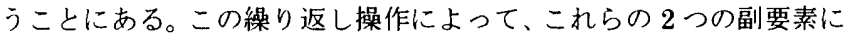
関する接線柔性マトリックスを更新していく。曲げはファイバーモデ ルにより、せん断は修正圧縮場理論（MCFT）に基づいたせん断力と せん断ひずみの構成則と、Filippou の履歴則を用いて計算する。2つ の柔性マトリックスは直列つなぎのば好として計算される。

\section{2. モデルの基碳}

柱要素は図ー1に示寸ように、曲げとせん断の副要素に分割される。 曲げひずみの断面内分布仮定にはベルヌーイ・オイラーの仮定が用い られる。曲げモーメントとせん断力の相互作用は、それぞれの副要素 の組み合わせで行われる。曲げ要素の柔性はファイバーモデルで、せ ん断要素は陽なせん断力とひずみの履歷則でそれぞれ計算される。せ ん断の履歷則は最初に MCFT モデルから得られたせん断力とひずみ のスケルトンカーブを利用し、その後 Filippou が提案した履歷則モ デルが採用される。しかしながら、せん断スパン比が小さい柱に対し て MCFTでは、せん断強度とその時のひずみが適切に求められない。 せん断成分 : 本せん断モデルは、 $\mathrm{RC}$ 部材の陽なせん断力とひずみ関 係に基づいている。部材のせん断力と材端モーメントの間には、力の 釣り合いを満足しなければならない。図ー2はせん断力とひずみに関 する典型的な非線形履歴則を示す。提案する非線形解析モデルの主要 な関心事は、RC 柱の解析に MCFTを応用することである。

曲げに関するファイバー副要素 : 柔性マトリックス法が RC 部材の曲 げ要素に分布した弾塑性モデルを、定式化するために適用される。そ の分布した弹塑性モデルは、数值積分点に位置したいくつかの断面で 表される。曲率と軸ひずみを含むどの断面変形に対しても、断面のた わみ性と断面力が、ファイバー手法を用いて計算される。

\section{3. 非線形手法の要約}

曲げの副要素で表現された断面の曲げ変形は、2つの成分からなる。 そのひとつは材軸に沿った軸ひずみをであり、あとのひとつは曲率中

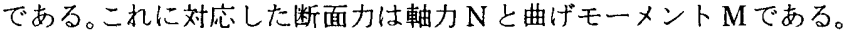
せん断の副要素では柔性マトリックスとせん断力が、(5) 式とせ ん断カーひずみの履歴側を利用して直接計算される。解析では、要素 レベルにおけるカー変位関係が増分形式で通常表示される。2つの副 要素荷重増分（曲げとせん断）は、曲げとせん断スプリングが直列に つながれていることに相当するので、柱要素としても同じ荷重増分に なる。材軸に沿った力の釣り合いは力の内挿関数を用いて箃密に満足 され、次第に增加する非線形の変位成分（曲げとせん断成分）が正確
に決定される。非線形解析のフローチャートは図ー6に示す。本非線 形解析と従来の非線形解析の相違は、従来の方法が形状関数を利用し て要素の直接剛性マトリックスを更新していたのに対し、柔性マトリ ックスに基䃈を掞いた本方法は、その柔性マトリックスを最初に更新 し、その後の逆マトリックス計算で、判性マトリックスを求める。

4. 材料構成則モデル

本非線形解析で用いる材料の構成則モデルは、ファイバーモデルに よる曲げと、陽な形式で与えられるせん断力とひずみの関係の導出に 重要な役割を担う。せん断に関してはコンクリートの圧縮と引っ張り の構成則が、MCFT によるせん断ひび割れに依存する。曲げに関し ては一般に 3 つの構成則モデルが必要である。すなわち、1）アンコ ンファインドコンクリート、2）コンファインドコンクリートと３） 座屈の有無による鉄筋の構成則である。

能動的/受動的拘束効果: 能動的拘束効果はひび割れとは無関係に、 $\mathrm{PC}$ 鋼棒に緊張力を導入して生じる横拘束力である。一方、受動的拘 束効果はひび割れに伴い、横補強筋として働く横拘束力である。

\section{5. 関連研究}

\section{1 柱試䀦体}

選ばれた柱試験体 6 体を材料特性、断面詳細、補強法など含めて、 表ー 1 と図 -8 に示す。柱試験体の举動を検討するために、せん断ひ び割れ強度、せん断強度、付着強度や曲げ強度などが AIJ 勒性指針 式で、曲げせん断ひび割れ強度が ACI 式で計算される。これらの計 算結果と実験結果を表ー 2 に示寸。せん断ひび割れ強度に及ぼすブレ ストレスの効果を図ー9に示す。

\section{5 . 2 修正圧縮場理論（MCFT）の修正}

修正圧縮場理論（MCFT）とは？：MCFT は平面せん断応力と垂 直応力を受ける RC 要素の、せん断力とせん断ひずみを評価する解析 モデルである。

MCFT の不十分さ : せん断スパン比の小さいせん断破壊タイプの $\mathrm{RC}$ 要素のせん断強度と、その時のせん断ひずみを $\mathrm{MCFT}$ では、精 度良く評価できない。

MCFT の修正：MCFTに関する修正を、せん断と曲げ破壊に分け て以下のように試みる。

せん断破液：1）MCFTでせん断力とせん断ひずみの関係をまず 求める、2) せん断強度を MCFT、AIJ、修正荒川式などで求める、 3) せん断ひずみが $0.4 \%$ 時のせん断強度の点（富井・武内の研究成 果) と、その半分の点を結ぶ、4) 軟化域はせん断強度の点から MCFT で求めた原曲線に、平行にとる。

曲げ破壊：MCFTによる曲げ破壊時のせん断力とせん断ひずみ関 係の修正方法は、MCFT で求められた単調カーブに扔いて、ひび割 れ前後の剛性をそれぞれ減少させることによって与えられる。

\section{5 . 3 実験と解析の比較}

せん断破壊と曲げ破壊に関する実験結果と解析結果の比較が、図一 13 と図一 14 に示される。解析結果は実験結果によく合っている。す 心゙ての基準試験体はせん断破壊タイプであるので、全変形の履歷はせ ん断の副要素に支配され、かつ主筋は降伏していない。曲げ破壊タイ プの耐震補強試験体では、主筋が降伏寸る前はせん断変形の影響が大 きい。しかしながら、主筋降伏後の弹塑性举動は曲げに支配される。

\section{6. 結論}

材軸に沿って分布させたファイバーモデルを用いて得られた曲率 から曲げ举動を求め、陽なせん断力とひずみ関倸からせん断举動を求 める本非線形解析は、 RC 部材の非線形解析に威力を発揮した。せん 断力とひずみ関係を修正するための本提案は、実験デ一タと AIJ 勒 性指針式や修正荒川式などに基づいているものの、MCFT（修正圧縮 場理論) の結果を改良するために適用される。せん断破買が先行寸る 短柱に関して、PC 鋼棒に緊張力を導入して耐震補強を行う前と後の 弹塑性举動が、本解析手法によって自動的に予測できる。解析結果は、 せん断破壊先行タイプの柱に緊張力を導入した PC 鋼棒を用いて行 う耐震補強法が、きわめて効果的であることを示している。また、こ れらの解析結果は実験結果によく一致していることもわかった。 